\title{
S12 Table
}

\begin{tabular}{|c|c|c|c|}
\hline & Dynamics + Noise & Dynamics & Noise \\
\hline$E_{v}$ & 0.0476 & 0.0398 & 0.3246 \\
\hline$E_{a}$ & 0.0626 & 0.1386 & 0.1292 \\
\hline$E_{\omega}$ & 0.0731 & 0.0630 & 0.0546 \\
\hline$E_{\alpha}$ & 0.1102 & 0.1299 & 0.1409 \\
\hline$E_{\mu}$ & 0.0141 & 0.0269 & 0.0327 \\
\hline$E_{d}$ & 0.0097 & 0.0238 & 0.0275 \\
\hline$E_{\eta}$ & 0.0930 & 0.0354 & 0.0700 \\
\hline total score & 0.7253 & 0.4656 & 0.2085 \\
\hline
\end{tabular}

